\title{
Pelatihan Membaca Gambar Teknik Untuk Tim Sales Dan Produksi Pada PT. ISTW Jakarta
}

\author{
Ariya Purnamasari Dewi*1, Casban $^{2}$, Umi Marfuah ${ }^{3}$, Didi Sunardi ${ }^{4}$ \\ 1,2,3,4 Program Studi Teknik Industri, Fakultas Teknik, Universitas Muhammadiyah Jakarta, Indonesia \\ *e-mail: ariya.purnamasari@umj.ac.id ${ }^{1}$, casban@umj.ac.id², umi.marfuah@umj.ac.id ${ }^{3}$, \\ didi.sunardi@umj.ac.id ${ }^{4}$
}

\begin{abstract}
Abstrak
Pelatihan membaca gambar teknik tidak banyak ditawarkan di pasaran, sehingga mitra mengalami kendala dalam ketersediaan nara sumber yang dapat memberikan materi. Pelatihan ini merupakan kegiatan pengabdian masyarakat tim Dosen Teknik Industri UMJ yang bertujuan untuk memberikan pengetahuan dan pemahaman dalam membaca gambar teknik. Mitra kerjama dalam kegiatan pengabdian masyarakat adalah PT. Indonesia Steel Tube Works (ISTW) Jakarta. Alur langkah kegiatan pengabdian masyarakat dilakukan melalui identifikasi masalah yang terjadi pada mitra, menentukan skala prioritas yang perlu dilakukan tindakan perbaikan, problem solving dengan memberikan pelatihan, feedback berupa evaluasi peninjauan hasil kegiatan pelatihan. Tahapan kegiatan pelatihan yang dilakukan meliputi presentasi materi pelatihan, diskusi, tanya jawab dan evaluasi pelatihan. Pelaksanaan kegiatan pelatihan dilakukan secara daring dengan menggunakan aplikasi video converence zoom meeting. Materi pelatihan membaca gambar teknik mencakup 4 topik yang meliputi standarisasi, mendeskripsikan gambar teknik, simbol las dan toleransi. Hasil kegiatan pelatihan membaca gambar teknik dalam pengabdian masyarakat untuk tim sales dan produksi PT. ISTW sebagai peserta pelatihan sudah mendapatkan pengetahuan dan pemahaman dalam membaca gambar teknik. Berdasarkan hasil evaluasi kegiatan pelatihan yang sudah dilakukan menyatakan bahwa pelatihan dapat memperluas keilmuan gambar teknik sehingga mitra dapat meningkatkan kemampuan dan keterampilan dalam pelaksanaan tugas dan tanggung jawab pekerjaan yang ada di perusahaan.
\end{abstract}

Kata kunci: Pengabdian masyarakat, Gambar Teknik, PT. ISTW

\begin{abstract}
Training on reading technical drawings is not widely offered in the market, so partners experience problems in the availability of resource persons who can provide material. This training is a community service activity for the UMJ Industrial Engineering Lecturer team which aims to provide knowledge and understanding in reading technical drawings. Partners in community service activities are PT. Indonesia Steel Tube Works (ISTW) Jakarta. The flow of community service activities is carried out through identifying problems that occur with partners, determining priority scales that need corrective action, problem solving by providing training, feedback in the form of evaluating the results of training activities. The stages of training activities carried out include presentation of training materials, discussions, questions and answers and training evaluations. The implementation of training activities is carried out online using the video conference zoom meeting application. The training material for reading technical drawings covers 4 topics including standardization, describing technical drawings, welding symbols and tolerances. The results of training activities to read technical drawings in community service for the sales and production team of PT. ISTW as training participants have gained knowledge and understanding in reading technical drawings. Based on the results of the evaluation of the training activities that have been carried out, it is stated that the training can expand the knowledge of technical drawing so that partners can improve their abilities and skills in carrying out the duties and responsibilities of work in the company.
\end{abstract}

Keywords: Community service, technical drawing, PT. ISTW.

\section{PENDAHULUAN}

Gambar teknik digunakan sebagai bahasa dalam bidang teknik yang berisi informasi dan data mengenai suatu benda yang akan dikerjakan berdasarkan spesifikasi standar tertentu yang sudah ditetapkan, sehingga diperlukan keterampilan dan pengetahuan untuk dapat memenuhi perkembangan teknologi. Gambar teknik mempunyai fungsi untuk menjelaskan informasi dari perancang secara benar sehingga tidak terjadi keslahan dalam tahapan proses perencana, proses 
produksi, perakitan dan inspeksi. Gambar perlu di tafsirkan sebagai penentuan secara obektif, untuk itu dibuat sebuah standar yang digunakan sebagai tata bahasa teknik yang berfugsi untuk menyediakan ketentuan ketentuan yang cukup [1].

Gambar teknik mempunyai peranan yang penting dalam tahapan perencanaan dan perancangan sebelum produk dibuat dalam tahapan proses produksi dan perakitan. Dalam tahapan pembuatan gambar teknik ada aturan dan ketentuan tertentu yang sudah menjadi kesepakatan dalam bidang teknik [2]. Gambar teknik mempunyai fungsi untuk menjelaskan informasi dengan menggunakan data teknis untuk menjelaskan keterangan dan konsep perencanaan yang dapat disiapkan sebagai bahan informasi [3]. Tujuan dari gambar teknik untuk menjelaskan gagasan dari perancang gambar secara jelas dan obyektif dengan menggunakan simbol tertentu sesuai standar yang sudah ditetapkan. Simbol-simbol yang digunakan dalam gambar teknik sudah dibuat sesuai standar yang sudah diterapkan diseluruh dunia yaitu standar ISO dan standar tertentu yang berlaku di suatu negara [4].

Dalam gambar teknik dapat dibuat dalam bentuk gambar sketsa manual namun untuk mendapatkan data yang lebih mendekati bentuk asli bendanya maka perlu dikembangkan dalam bentuk gambar 3D untuk memudahkan dalam melakukan koreksi dari desain gambar yang sudah dibuat. Salah satu perangkat lunak yang dapat dimanfaatkan untuk mendesain gambar 3D adalah Autodesk Inventor [5]. Dalam proses membuat desain gambar teknik, diperlukan beberapa sisi pandangan atau proyeksi gambar untuk menjelaskan bentuk suatu benda yag dapat dituangkan menjadi gambar proyeksi 2 dimensi. Pemahaman terhadap gambar proyeksi sangat dibutuhkan dalam proses desain gambar teknik, selain itu diperlukan kemampuan untuk dapat membaca gambar teknik, meskipun tingkat kesulitan dalam proses membuat desain gambar lebih tinggi jika dibandingkan membaca gambar. Dalam membuat desain gambar teknik untuk memberikan penjelasan mengenai bentuk asli suatu benda, maka dapat dibuat dalam bentuk gambar proyeksi dalam arah pandang yang berbeda.

Perangkat lunak komputer merupakan suatu program data-data elektronik yang tersimpan didalam komputer yang digunakan untuk mengoperasikan perintah tertentu. Perangkat lunak atau sofeware dapat disebut sebagai suatu sistem opearsi untuk menerjemahkan suatu perintah yang dibuat oleh pengguna untuk dijalankan atau diproses dengan menggunakan perangkat keras. Software gambar teknik merupakan perangkat lunak yang berisi perintah-perintah komputer untuk membantu proses pembuatan gambar teknik [6]. Dalam proses pembuatan suatu bentuk benda, maka akan membutuhkan kemampuan dalam memaahami gambar teknik, sehingga kemampuan membaca gambar teknik sebagai hal yang penting untuk dapat menguasai hal-hal yang ada pada gambar teknik. Informasi data yang ada dalam gambar teknik tersebut dapat diteruskan dalam tahapan proses produksi sesuai dengan spesifikasi yang tercantum dalam gambar teknik. Kemampuan membaca gambar teknik sangat diperlukan karena dalam gambar teknik banyak terdapat simbol ataupun lambang dan harus dapat diketahui dan dipahami makna dari simbol yang adadalam gambar teknik. Untuk mempermudah dalam memahami gambar teknik dapat digunakan simbol dan gambar proyeksi. Kemampuan dalam membaca gambar teknik membutuhkan suatu pengetahuan tertentu sehingga dapat menginterpretasikan bentuk asli benda dengan melihat gambar teknik.

\section{Gambaran Mitra}

Mitra kerjama dalam kegiatan pengabdian masyarakat adalah PT Indonesia Steel Tube Works (ISTW) Jakarta sebagai perusahaan joint venture antara Indonesia dan Jepang yang berdiri pada tahun 1971. PT ISTW merupakan sebuah perusahaan yang memproduksi tabung baja dengan kapasitas produksi yang besar dan sudah memiliki pengalaman lebih dari 40 tahun. Perusahaan memberikan jaminan kualitas tabung baja yang diproduksi berdasarkan tiga kualitas utama yaitu presisi yang sangat baik, pengujian yang baik dan layanan pengiriman dengan waktu yang tepat serta sebagai produsen tabung baja yang bersertifikat ISO dan SNI. Permintaan dan spesifikasi produk yang diberikan konsumen harus dapat dibaca, diterjemahkan, dan diwujudkan dengan produk yang sesuai standar teknik yang berlaku. Untuk itu diperlukan SDM yang memiliki pemahaman ekselen dalam mendefinisikan standar teknik tersebut dimulai dengan penerapannya dalam desain produk berupa gambar teknik, pembacaannya, hingga produksi dan pengecekan hasil sehingga terwujud persepsi yang sama. 
PT ISTW membentuk pekerjanya sebagai seorang yang profesional sehingga salah satu upaya untuk memastikan mereka menguasai bidang mereka, secara regular diperlukan refreshing atau training untuk mempertajam pengetahuannya. Dari beberapa jenis training standar yang diperlukan pekerja saat ini adalah pembacaan dan intepretasi gambar teknik karena awal mula kualitas produk mereka berasal dari proses tersebut. Permasalahan yang dihadapi PT ISTW adalah pelatihan membaca gambar teknik bukanlah termasuk jenis yang banyak ditawarkan di pasaran, sehingga masih mengalami kendala dalam penyelenggaraan dan ketersediaan nara sumber yang dapat memberikan materi pelatihan untuk meningkatkan pengetahuan dan kemampuan dalam membaca gambar teknik.

\section{Identifikasi Masalah}

Tahapan identifikasi masalah berdasarkan uraian yang sudah dijelaskan, maka pelatihan membaca gambar teknik diperlukan untuk memberikan pemahaman dalam membaca perspektif atau proyeksi gambar, skala gambar, dimensi atau ukuran, toleransi, gambar potongan, simbol dan unit pengukuran. Dengan adanya pelatihan tersebut maka dapat menunjang keilmuan bagian sales dan bagian produksi dalam memastikan kesesuaian produk berdasarkan keinginan dan desain yang diajukan konsumen, sehingga dapat mengurangi kemungkinan terjadinya kesalahan dalam membaca gambar teknik yang dapat menyebabkan terjadi kesalahan bentuk atau desain, kesalahan proses produksi dan pengulangan produksi yang dapat mengakibatkan kerugian bagi perusahaan.

\section{Tujuan pelatihan}

Berdasarkan identifikasi permasalahan tersebut maka Prodi Teknik Industri FT UMJ bermaksud memenuhi kebutuhan PT ISTW dengan memberikan pelatihan yang berkaitan dengan keilmuan gambar teknik dalam bentuk kegiatan pengabdian masyarakat. Tujuan yang ingin dicapai dalam kegiatan pengabdian masyarakat ini yaitu untuk memberikan pengetahuan dan pemahaman dalam membaca gambar teknik.

\section{Solusi dan Target Luaran}

Untuk memberikan solusi pemecahan masalah yang dihadapi oleh mitra dalam kegiatan pengabdian masyarakat, maka dilakukan kegiatan pelatihan membaca gambar teknik untuk tim sales dan produksi pada PT. ISTW Pulogadung. Tahapan kegiatan pelatihan yang dilakukan meliputi presentasi materi pelatihan, diskusi, tanya jawab dan evaluasi pelatihan. Target yang ingin dicapai mitra dalam kegiatan pengabdian masyarakat adalah memperluas keilmuan gambar teknik sehingga mitra dapat meningkatkan kemampuan dan keterampilan dalam pelaksanaan tugas dan tanggung jawab pekerjaan yang ada di perusahaan dengan lebih baik dan dapat mengurangi kesalahan dalam memahami gambar teknik. Gambaran permasalahan dan kerangka pemecahan masalah pada gambar 1.

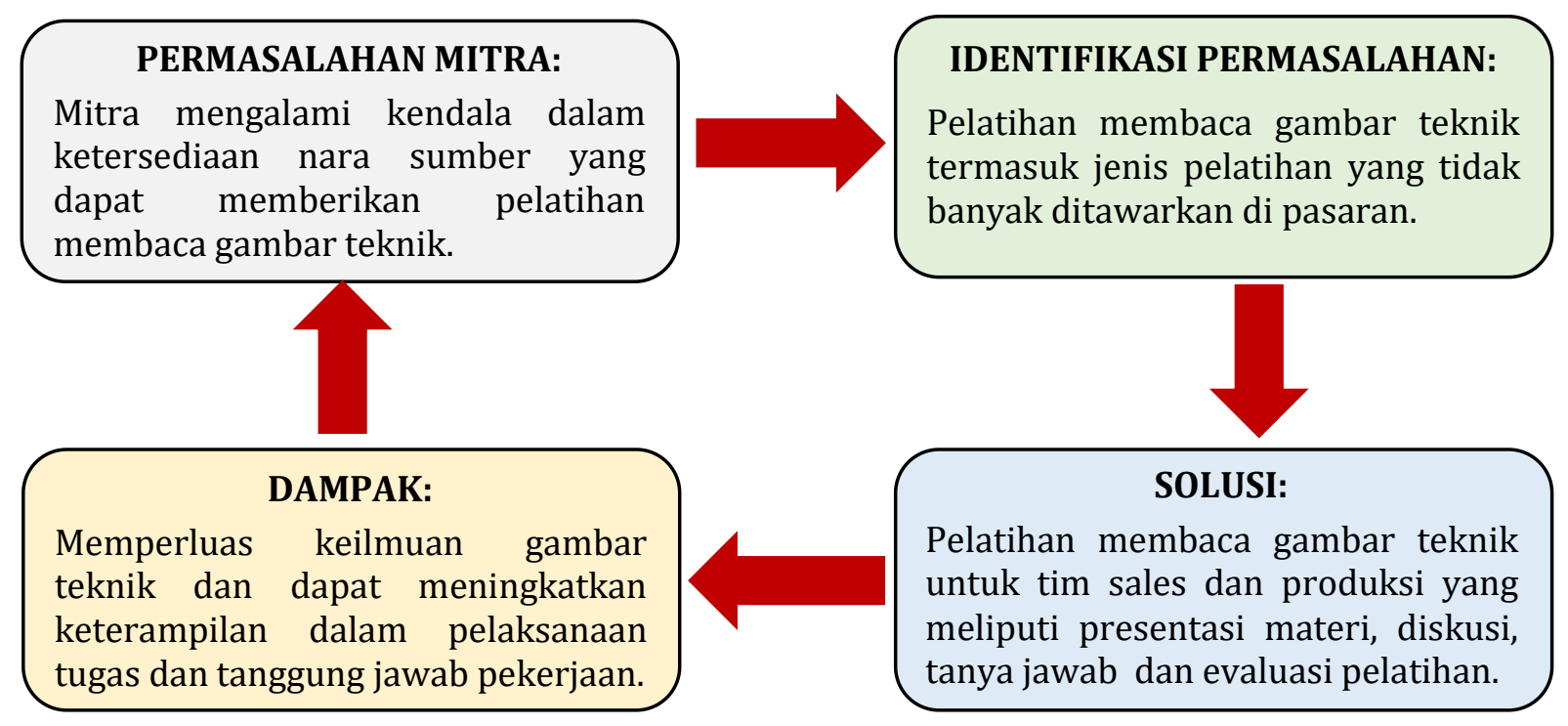

Gambar 1. Kerangka pemecahan masalah. 


\section{METODE}

Mitra dalam kegiatan pengabdian masyarakat adalah PT Indonesia Steel Tube Works Ltd yang berlokasi di Kawasan Industri Pulogadung Blok 11. AA 3-6, Jl. Rw. Sumur I, RW.9, Jatinegara, Kecamatan Cakung, Jakarta Timur. Kegiatan pelatihan dilaksanakan pada tangal 26 Januari 2021. Dengan mempertimbangkan kondisi dalam pandemi covid-19 di wilayah Jakarta sehingga untuk mencegah penyebaran Covid-19, maka kegiatan pelatihan membaca gambar teknik dilaksanakan secara online menggunakan zoom meeting. Peserta pelatihan diikuti oleh tim sales dan produksi PT. ISTW, mahasiswa dan tim dosen teknik industri UMJ.

Alur langkah kegiatan pengabdian masyarakat dilakukan melalui 1) Identifikasi masalah yang terjadi pada mitra yang menjadi obyek dalam kegiatan pengabdian masyarakat. Pada tahap awal ini dilakukan melalui diskusi dan wawancara dengan beberapa personel di bagian sales dan bagian produksi untuk mendapatkan informasi secara langsung dan melakukan eksplorasi dan pengamatan untuk mengidentifikasi permasalahan yang terjadi pada mitra; 2) Menentukan skala prioritas yang perlu dilakukan tindakan perbaikan melalui wawancara dengan kepala bagian sales sehingga dapat mengetahui gambaran umum terkait dengan kemampuan dalam membaca gambar teknik untuk merumuskan pokok permasalahan utama yang perlu segera dilakukan perbaikan; 3) Problem solving atau solusi optimal dengan memberikan pelatihan membaca gambar teknik yang dilakukan melalui kegiatan presentasi materi, diskusi, tanya jawab dan evaluasi pelatihan; 4) feedback atau umpan balik berupa evaluasi peninjauan hasil kegiatan pelatihan membaca gambar teknik yang sudah dilakukan secara bersama-sama. Alur langkah dalam metode pelaksanaan kegiatan pelatihan membaca gambar teknik pada gambar 2 .

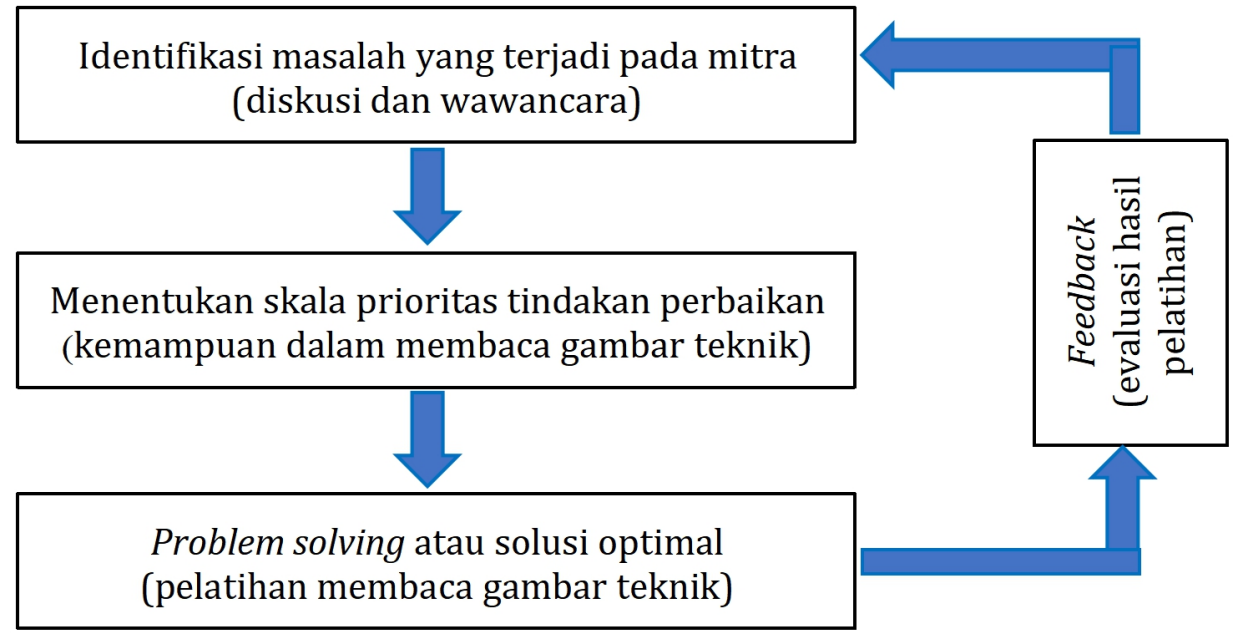

Gambar 2. Alur langkah kegiatan pengabdian masyarakat

Teknik pelaksanaan dalam kegiatan pelatihan membaca gambar teknik melalui tahap kegiatan yaitu 1) Presentasi dilakukan oleh tim dosen jurusan Teknik Industri UMJ dengan memberikan materi untuk menambah pengetahuan dan memperluas wawasan tentang membaca gambar teknik; 2) Diskusi sebagai bentuk sarana yang digunakan untuk menyampaikan pendapat sehingga dapat mempertemukan dan menyatukan persepsi, cara pandang dan wawasan pikiran terhadap materi pelatihan; 3) Tanya jawab dengan menyediakan kesempatan untuk berinteraksi dan membangun hubungan dengan peserta pelatihan untuk mengajukan pertanyaan mengenai materi yang masih belum dapat dipahami sehingga mendapatkan penjelasan yang lebih mendetail; 4) peninjauan hasil dilakukan oleh tim dosen untuk melakukan evaluasi rangkaian kegiatan pelatihan yang sudah dilakukan mulai dari presentasi materi, diskusi dan tanya jawab. Evaluasi pelatihan yang dilakukan mencakup beberapa pertanyaan yang digunakan untuk mengetahui dalam aspek tujuan, sasaran program, pengajar, fasilitas atau sarana, bobot materi, metode mengajar, performance mengajar, hasil yang diperoleh mitra, dampak dan kualitas lulusan. 


\section{HASIL DAN PEMBAHASAN}

Kegiatan pelatihan yang dilakukan dengan menggunakan video converence zoom meeting diikuti oleh perserta yang berada di lokasinya tempat tinggalnya masing-masing karena masih menerapkan WFH (work from home) dan sebagai peserta yang masuk kantor dari tim sales dan produksi PT.ISTW berada di ruang training. Kegiatan pelatihan dimulai dengan pembukaan, kemudian dilanjutkan dengan kata sambutan dari perwakilan dari PT. Indonesia Steel Tube Works dan perwakilan dari Fakultas Teknik Industri UMJ, kemudian dilanjutkan penyampaian materi pelatihan oleh tim dosen. Dokumentasi peserta pelatihan pada gambar 3.

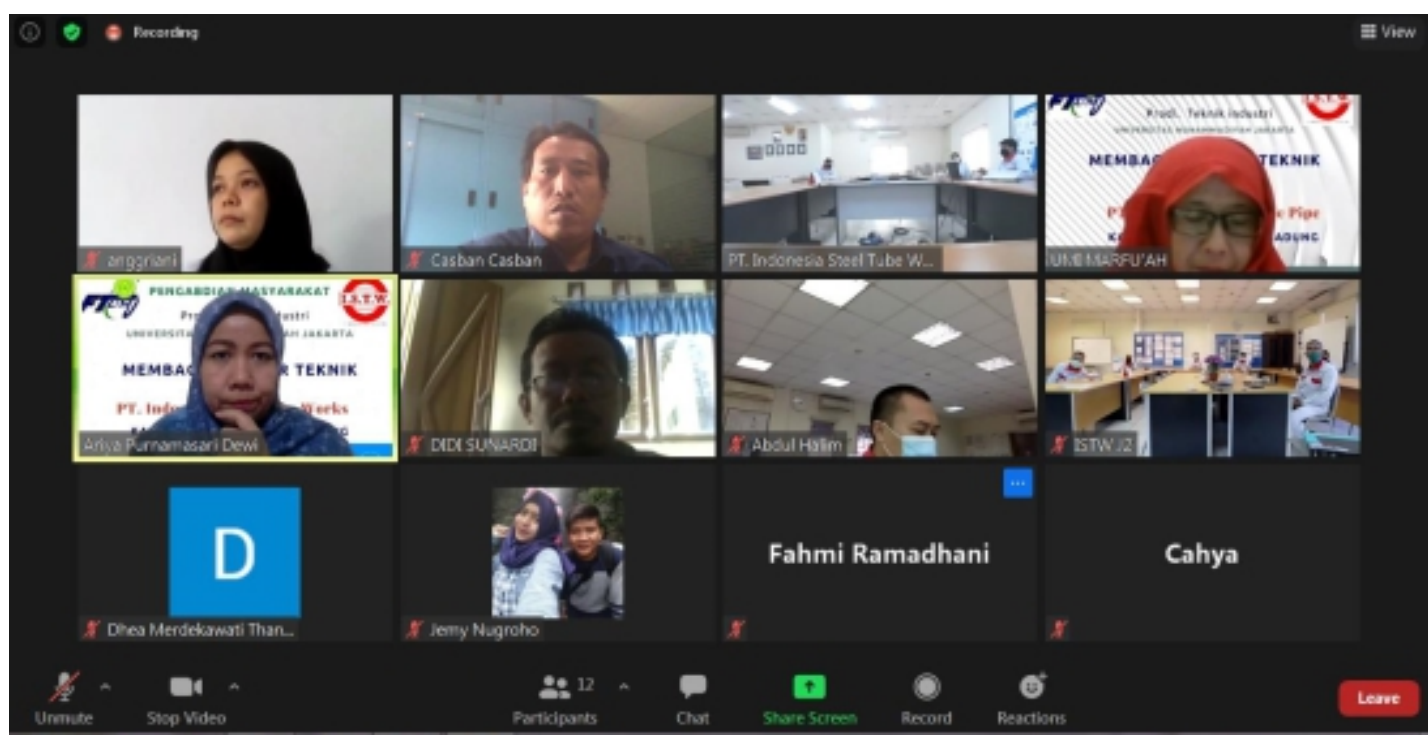

Gambar 3. Peserta pelatihan membaca gambar teknik

Materi pelatihan membaca gambar teknik mencakup 4 topik yang meliputi standarisasi, mendeskripsikan gambar teknik, simbol las dan toleransi. Gambar merupakan suatu alat untuk berkomunikasi dalam menyampaikan pesan tertentu dari pembuat gambar, sehingga gambar dapat digunakan menjadi bahasa dalam bidang teknik. Bentuk penyampaiaan informasi merupakan suatu fungsi yang penting dalam membuat gambar. Oleh karena itu gambar diharapkan dapat menjelaskan tentang data dan keterangan yang tepat dan obyektif. Keterangan yang tertulis dalam gambar yang tidak dapat dinyatakan dengan bahasa lisan, namun harus dibuat dalam bentuk suimbol atau lambang tertentu, sehingga untuk menjaga kualitas keterangan dan informasi data yang akan disampaikan akan dipengaruhi kemampuan dari juru gambar (drafter). Dalam membuat gambar teknik, seorang juru gambar diharapkan dapat menjelaskan informasi yang tepat sehingga dapat dipahami dengan mudah oleh pembacanya. Dalam membaca gambar teknik, hal perlu diperhatikan adalah memahami informasi dan keterangan yang ada dalam gambar teknik secara teliti. Dengan demikian gambar teknik mempunyai peranan yang penting dalam industri manufaktur yang dapat digunakan untuk menyusun perencanaan sebuah bentuk produk yang akan dibuat [7].

Standarisasi dalam gambar teknik mengacu berdasarkan standar ISO yang berfungsi untuk memberikan jaminan dan kepastian kesesuaian yang dapat diterima semua pihak yang mempunyai kepentingan berdasarkan kesepakan penggunaan aturan yang ada dalam gambar, menyamakan pemahaman dan penggunaan simbol yang dibuat dalam gambar teknik, sehingga dapat mempermudah komunikasi antara yang membuat gambar dan pihak lain yang membaca gambar serta dapat memudahkan kerjasama antara perusahaan dalam memproduksi benda teknik. Software pendukung gambar teknik meliputi AutoCAD, SolidWorks, Adobe Illustrator, Adobe Photoshop, Microsoft Visio, Microsoft Excel, dan lain-lain. SolidWorks merupakan sofeware yang dapat digunakan dalam proses desain and drawing. Dalam penggunaan SolidWorks memiliki peranan yang hampir sama dengan 3D parametric software yang lainnya, namun dalam SolidWorks mempunyai kelebihan dalam membuat desain lebih mudah [8]. 
Penggunaan aplikasi gambar secara digital mempunyai kelebihan dengan adanya fasilitas dan fungsi tertentu untuk mempermudah melakukan modifikasi gambar, namun mempunyai kelemahan dalam penggunaan aplikasi gambar secara digital jika listrik padam proses pekerjaan tidak dapat dilakukan [9]. Untuk dapat membaca gambar teknik, perlu mengetahui keterangan dan informasi yang tertulis pada gambar, sehingga untuk dapat mengetahui penjelasan informasi dalam gambar teknik, maka harus ada kesepakatan dan pemahaman yang sama sehingga informasi yang ada dalam gambar dapat dipahami secara benar dan tidak menimbulkan kesalahan. Kemampuan untuk dapat memahami, simbol, ukuran dan skala gambar dibutuhkan untuk dapat membaca gambar teknik dengan benar [10]. Dokumentasi materi tentang istilah dalam toleransi pada gambar 4.

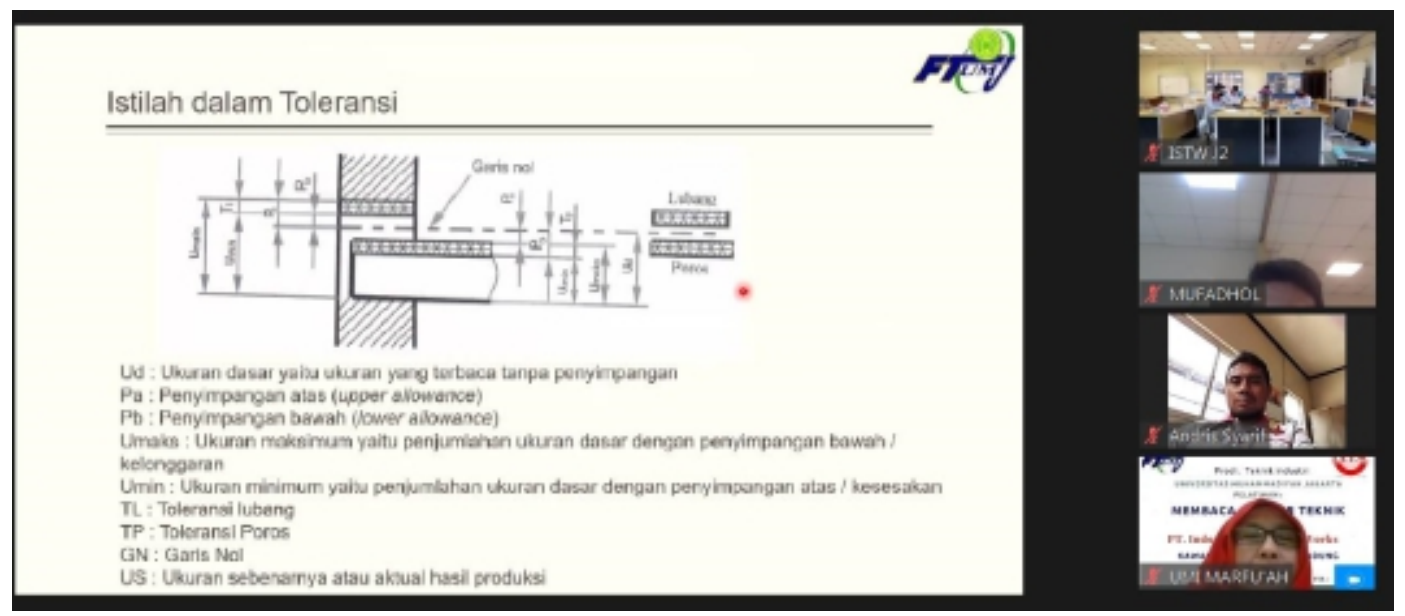

Gambar 4. Dokumentasi materi tentang istilah dalam toleransi

Proyeksi merupakan garis khayal untuk menggambarkan bentuk benda dengan membuat suatu garis pandang arah penglihatan dari sebuah bidang gambar. Proyeksi mempunyai fungsi untuk mennggambarkan bentuk benda dalam garis pandang dari beberapa arah yang diperukan. Proyeksi sebagai metode untuk menggambarkan titik, bidang, garis pandang suatu bentuk benda berdasarkan bidang gambar. Proyeksi piktorial merupakan cara pandangan gambar tiga dimensi yang mengacu pada bidang dua dimensi, hal ini berbeda degan proyeksi ortogonal yang menggambarkan bidang proyeksi dalam sudut tegak lurus terhadap sudut proyektor [11]. Dokumentasi materi tentang materi potongan pada gambar 5.

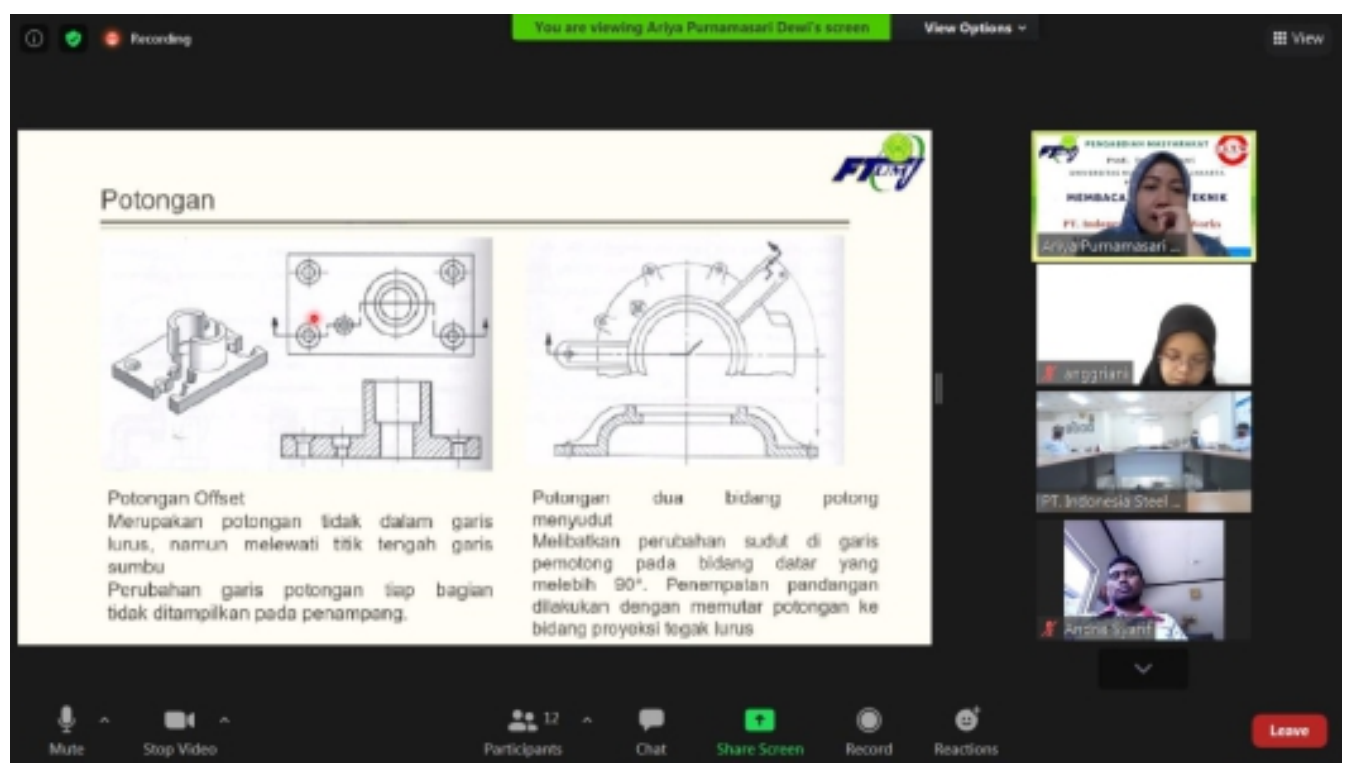

Gambar 5. Dokumentasi materi tentang potongan 
Simbol untuk menunjukkan sambungan las pada gambar teknik dengan sistem simbolisisasi Amerika adalah sistem AWS, yang diformulasikan oleh American Welding Society (AWS). Sistem ini digunakan secara luas di seluruh dunia, terutama karena industri minyak, dan saat ini digunakan oleh sekitar setengah industri pengelasan dunia. Seluruh dunia menggunakan sistem ISO, yang dirancang oleh Internasional Standardisasi Organisasi (ISO). Namun, sejumlah negara, terutama yang memiliki tautan perdagangan luas, dapat menggunakan satu sistem di negara mereka sendiri tetapi perlu menggunakan yang lain untuk memenuhi persyaratan pelanggan di luar negeri. Oleh karena itu perlu adanya perbandingan kedua sistem tersebut. Dokumentasi materi tentang kode proses pengelasan pada gambar 6.

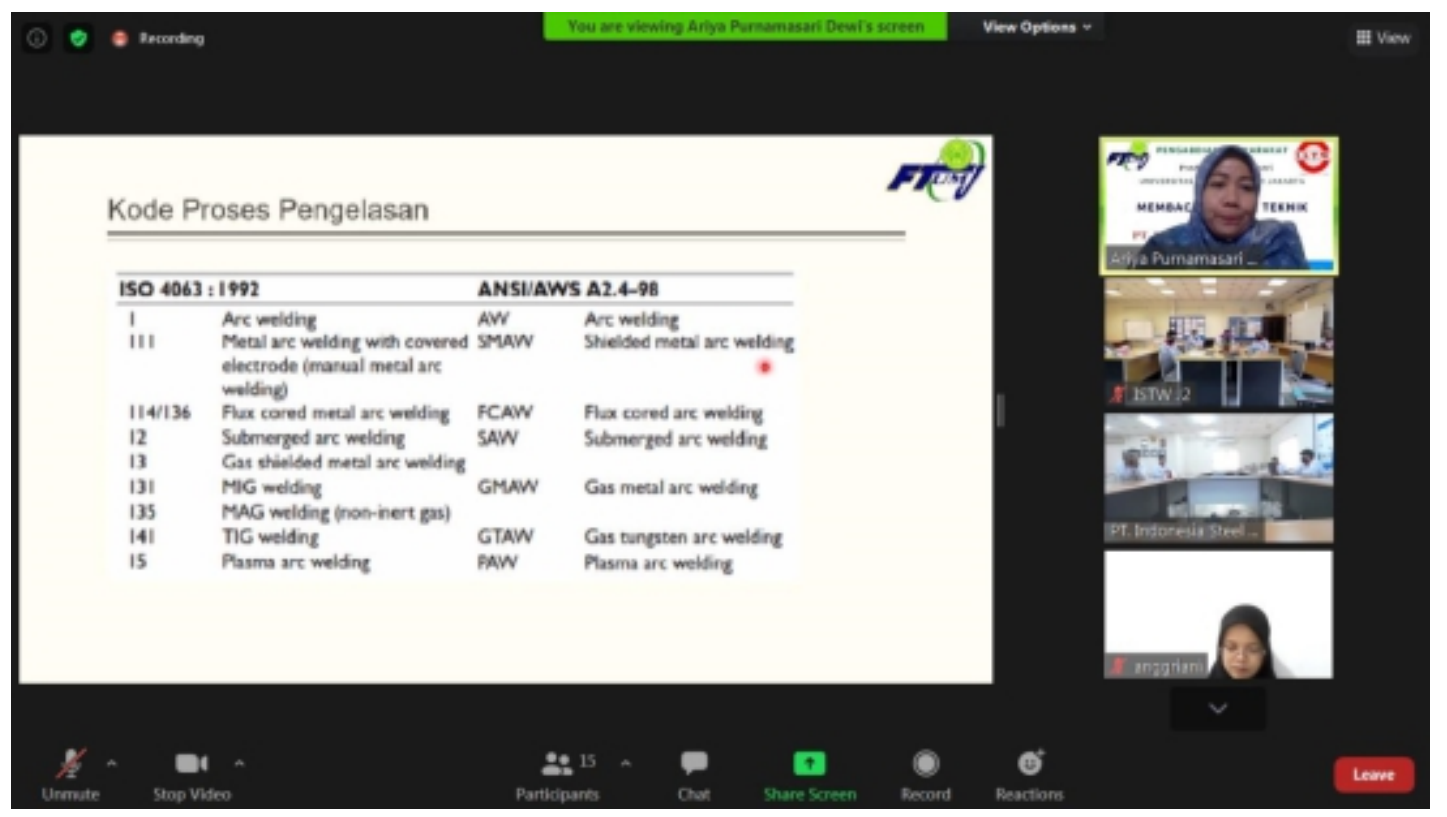

Gambar 6. Dokumentasi materi tentang kode proses pengelasan

Toleransi ukuran adalah perbedaan ukuran antara kedua harga ukuran atau jarak batas maksimum dengan batas minimum yang dapat dinyatakan sebagai penyimpangan yang diizinkan. Istilah dalam toleransi mencakup Ud (ukuran dasar yaitu ukuran yang terbaca tanpa penyimpangan), $\mathrm{Pa}$ (Penyimpangan atas atau upper allowance), $\mathrm{Pb}$ (penyimpangan bawah atau lower allowance), U-maks (ukuran maksimum yaitu penjumlahan ukuran dasar dengan penyimpangan bawah sebagai batas kelonggaran), U-min (ukuran minimum yaitu penjumlahan ukuran dasar dengan penyimpangan atas sebagai batas kesesakan), TL (toleransi lubang), TP (toleransi poros), GN (garis nol), US (ukuran sebenarnya atau aktual hasil produksi).

Setelah penjelasan materi pelatihan selesai, maka dilanjutkan dengan sesi diskusi dan tanya jawab dengan memberikan kesempatan kepada peserta pelatihan untuk menyampaikan pertanyaan maupun pendapat tentang penjelasan materi yang sudah disampaikan sehingga mendapatkan penjelasan yang lebih mendetail dan dapat menyatukan persepsi, cara pandang dan wawasan pikiran terhadap materi pelatihan. Hasil pelatiahan terebut sejalan dengan penelitian yang lain menyatakan bahwa terdapat pengaruh positif dan signifikan kemampuan membaca gambar teknik terhadap kerja pemesinan dan mempunyai keterkaitan hubungan secara erat antara membaca gambar teknik dengan kerja pemesinan [12].

Pada bagian akhir kegiatan pelatihan dilakukan evaluasi untuk peninjauan hasil rangkaian kegiatan pelatihan yang sudah dilakukan mulai dari presentasi materi, diskusi dan tanya jawab. Adanya evaluasi dapat memudahkan pengambilan keputusan [13]. Hasil evaluasi pelatihan berdasarkan jawaban yang diberikan oleh peserta menyatakan bahwa pelatihan membaca gambar teknik sudah memberikan manfaat untuk memperluas wawasan dan pengetahuan, peserta merasa tertarik untuk mengikuti pelatihan karena topik bahasan materi 
diperlukan dalam pelaksanaan tugas pekerjaan di Perusahaan serta dapat meningkatkan keterampilan dalam bekerja, sehingga dapat mengurangi kesalahan membaca gambar teknik.

Hasil evaluasi kegiatan pelatihan ini sesuai dengan penyusunan kriteria evaluasi antara lain yang mencakup tujuan dan target, waktu pencapaian, tingkat pengaruh yang diinginkan, perubahan perilaku masyarakat, pelajaran yang diperoleh para pelaksana proyek dan tingkat kesadaran masyarakat akan kemampuan dirinya [14]. Evaluasi pelatihan merupakan suatu aktivitas yang dirancang untuk menilai hasil program dan proses yang bervariasi dalam spesifikasi kriteria, teknik pengukuran, metode analisis dan bentuk rekomendasinya [15]. Evaluasi pelatihan memiliki tujuan yaitu menentukan tingkat kinerja, mengukur tingkat efisiensi, mengukur tingkat keluaran, mengukur dampak dari pelaksanaan kegiatan dan bahan masukan untuk perbaikan di masa mendatang [16].

Berdasarkan hasil diskusi dengan peserta pelatihan menyatakan bahwa sebelum dilakukan kegiatan pelatihan membaca gambar teknik, mitra masih belum memahami secara mendetail mengenai materi gambar proyeksi sebagai kemampuan yang dibutuhkan untuk dapat memahami bentuk asli suatu benda yang dibuat dalam suatu garis pandang arah penglihatan dari sebuah bidang gambar dalam arah pandang yang berbeda. Sebelum dilakukan kegiatan pelatihan mitra menyatakan bahwa masih belum mengetahui secara mendalam tentang standarisasi yang digunakan dalam gambar teknik yang mengacu standar ISO, hal ini menjadi penting karena dengan adanya standarisasi penggunaan simbol yang dibuat dalam gambar teknik, maka dapat mempermudah komunikasi dan kerja sama antara bagian yang ada di perusahaan dalam memproduksi benda teknik. Kemampuan untuk dapat memahami, simbol, ukuran dan skala gambar dibutuhkan untuk dapat membaca gambar teknik dengan benar, sehingga dapat mengurangi terjadinya kesalahan yang disebabkan adanya kesalahan dalam memahami standarisasi penggunaan simbol dalam gambar teknik. Sebelum dilakukan kegiatan pelatihan mitra menyatakan bahwa masih belum memahami secara mendalam mengenai materi skala gambar, toleransi dan unit pengukuran.

Hasil setelah dilaksanakan kegiatan pelatihan membaca gambar teknik berdasarkan hasil evaluasi kegiatan pelatihan dapat diketahui bahwa terdapat perbedaan hasil sebelum dan setelah dilaksanakan kegiatan pelatihan membaca gambar teknik yaitu dapat memperluas keilmuan gambar teknik sehingga mitra dapat meningkatkan kemampuan dan keterampilan dalam pelaksanaan tugas dan tanggung jawab pekerjaan yang ada di perusahaan dengan lebih baik dan dapat mengurangi kemungkinan terjadinya kesalahan dalam membaca gambar teknik yang dapat menyebabkan kesalahan menginterpretasikan desain produk yang akan dibuat yang akan memberikan dampat terhadap terjadinya kesalahan dalam tahapan proses produksi yang dapat mengakibatkan kerugian bagi perusahaan. Dengan adanya pelatihan tersebut maka dapat menunjang keilmuan bagian sales dan bagian produksi dalam memastikan kesesuaian produk berdasarkan keinginan dan desain yang sudah dibuat oleh konsumen.

\section{KESIMPULAN}

Kegiatan pelatihan membaca gambar teknik dalam pengabdian masyarakat untuk tim sales dan produksi PT. ISTW sebagai peserta pelatihan sudah mendapatkan pengetahuan dan pemahaman dalam membaca gambar teknik yang berkaitan dengan pokok bahasan materi tentang standarisasi, mendeskripsikan gambar teknik, simbol las dan toleransi. Berdasarkan hasil evaluasi kegiatan pelatihan membaca gambar teknik yang sudah dilakukan dapat memperluas keilmuan gambar teknik sehingga mitra dapat meningkatkan kemampuan dan keterampilan dalam pelaksanaan tugas dan tanggung jawab pekerjaan yang ada di perusahaan dengan lebih baik dan dapat mengurangi kesalahan dalam membaca gambar teknik. 


\section{UCAPAN TERIMA KASIH}

Ucapan terimakasih untuk Lembaga Penelitian dan Pengabdian Masyarakat (LPPM), Fakultas Teknik dan Program Studi Teknik Industri Universitas Muhammadiyah Jakarta yang telah banyak memberikan bantuan dana dalam kegiatan pengabdian masyarakat.

\section{DAFTAR PUSTAKA}

[1] G. T. Sato, N. S. Hartanto, "Menggambar Mesin Menurut Standar ISO". Jakarta: PT. Balai Pustaka (Persero), 2013

[2] G. Purwanto, "Menggambar Teknik Dasar". Yogyakarta: Kanisius. 2002

[3] J. Santoso, "Gambar teknik Mesin 1: untuk SMK/MAK Kelas XII". Malang: Pusat Pengembangan \& Pemberdayaan Pendidik \& Tenaga Kependidikan Bidang Otomotif \& Elektronika. 2013.

[4] Juhana." Menggambar teknik mesin dengan standar ISO". Bandung: Pustaka Grafika. 2012

[5] V. T. Widyaningrum, Y. F. Hendrawan, S. Wahyuni. "Menggambar teknik dengan Teknologi 3 Dimensi Bagi Guru dan Siswa SMKN di Bangkalan". Jurnal ilmiah Pangabdhi. vol.3, no.2, h.7-12. 2018.

[6] A. F. Vebrianingtyas. "Gambar teknik SMK/MAK Kelas X". Jawa Timur: PT Kuantum Buku Sejahtera. 2020.

[7] Giesecke, Mitchell, Spencer, Hill, Dygdon, Novak, "Gambar Teknik Jilid 1". Jakarta: Erlangga. 2001.

[8] N. Hidayat, "SolidWorks 3D Drafting and Design". Bandung: Informatika. 2013.

[9] S. AlFajri dan I. N. Nasution. "Aplikasi menggambar teknik bangunan dengan menggunakan metode manual dan digital. Jurnal Education Building. vol.2, no.1, h.30-40. 2016.

[10] M. Nurtanto, "Intepretasi Gambar Teknik", Yogyakarta: Parama Publishing. 2016.

[11] J. La Heij dan L.A. De Bruijn, "Ilmu Menggambar Bangunan Mesin", Jakarta: Pradnya Paramita. 1999.

[12] A. Iswanda, Waskito, A. Aziz, D. Y. Sari. "Hubungan antara kemampuan membaca gambar teknik mesin dengan kemampuan kerja pemesinan pada siswa kelas X di SMK Negeri 2 Sawahlunto tahun pelajaran 2019/ 2020". Jurnal Vokasi Mekanika. vol.2, no.4, h.100-105. 2020.

[13] H. Kartini, B. L. Yuniawatika, \& S. E. Winahyu, "Pelatihan Penilaian Hasil Belajar untuk Meningkatkan Kompetensi Profesional Guru". Jurnal Abdimas Pedagogi, vol.1, no.1, h.3036. 2017.

[14] Wibawa, "Evaluasi Kebijakan Publik". Jakarta: PT. Raja Grafindo Persada. 2014.

[15] Suwitri. "Konsep Dasar Kebijakan Publik". Semarang: Universitas Diponegoro. 2010.

[16] Subarsono, "Analisis Kebijakan Publik, Konsep, Teori dan Aplikasi". Yogyakarta: Pustaka Pelajar. 2010. 